\title{
The Critical Success Factors Influencing the Quality of Accounting Information Systems and the Expected Performance
}

\author{
Omran Ahmad Mohammad Al-Ibbini ${ }^{1}$ \\ ${ }^{1}$ Accounting Department, Faculty of Business, Al Zaytoonah University of Jordan, Jordan \\ Correspondence: Omran Ahmad Mohammad Al-Ibbini, Accounting Department, Faculty of Business, Al \\ Zaytoonah University of Jordan, Jordan. Tel: 962-798-263-343. E-mail: o.alibbini@ zuj.edu.jo
}

Received: September 19, 2017

Accepted: October 31, 2017

Online Published: November 15, 2017

doi:10.5539/ijef.v9n12p162

URL: https://doi.org/10.5539/ijef.v9n12p162

\begin{abstract}
The ever-increasing complexities and controversial challenges in today's accounting and financial environment require organizations to adopt and use high-quality accounting information systems. The study aimed to develop a conceptual framework for exploring the critical success factors that affect the quality of accounting information systems and the expected performance. After reviewing extensively the related literature, the study's framework identified the quality of accounting information systems' critical factors in terms of top management support, education and training, continuous improvement, user involvement, and risk management. The quality of accounting information systems has seven dimensions which were accuracy, audit ability, reliability, security, timeliness, flexibility, and user satisfaction. Furthermore, the study's framework identified three major expected outcomes which are efficiency, effectiveness, and the integration of accounting and financial information from different sources.
\end{abstract}

Keywords: quality of accounting information system, expected performance, ethical conduct, ethical standards

\section{Introduction}

Recently, the quality of Accounting Information System (AIS) has received a lot of attention. Accounting can be considered as an information system that identifies, monitors, records, and communicates the economic events and financial position of an organization to its internal and external stockholders (Kieso, 2016). As a reaction to the important role of information in an organization, the organization becomes highly dependent on AIS (Susanto, 2013). The great development of IT has changed the way in which traditional accounting systems work. Grande et al. (2011) defined (AIS) as a tool designed to help in the management and control of topics related to firms' economic-financial areas. AIS can also be defined as a set of components that collects accounting data, and processes and sends information to many internal groups and interested parties who cooperate with each other in harmony to process the transaction data associated with financial problems into financial information (Susanto, 2013). Furthermore, with the advent of information technology and its applications, the recent AISs have provided high capabilities for decision-makers in the organization to evaluate and diagnose the dynamics of operations and financial circumstances effectively.

Laudon (2007) confirmed that if information in the organization has good quality, the organization will run well. AIS quality has become crucial for the success of accounting function in today's business age. The achievement of the basic activities of accounting function requires the application of the quality principles on AISs. Studies in evaluating the quality and value of information systems have identified information quality attributes as key indicators to measure the quality of AIS. Quality of information is generated by the quality of AIS and the quality of AIS are used to plan, implement, record, monitor, and control the financial activation and accounting transactions (Romney \& Steinbart, 2012).

Reviewing the related literature, there were very few attempts to identify the Critical Success Factors (CSFs) of the quality of AIS. Furthermore, a little attention has been paid to the study of the dimensions of AIS quality, CSFs, and the expected outcomes in a comprehensive framework. Therefore, the main goal of this paper is to develop a conceptual framework for exploring the critical success factors that affect the quality of accounting information systems and the expected performance. The knowledge of the CSFs that influences the quality of AIS helps organizations to improve their accounting information systems (AISs). 


\section{The Study's Problem}

The ever-increasing complexities and controversial challenges in today's accounting and financial environment require organizations to adopt and use high-quality accounting information systems. If the outputs of the accounting information system are not accurate, managers will take wrong decisions. Moreover, failure to implement properly AIS has adverse effect on the organization success.

\section{The Study's Significance}

Recently, accounting information systems (AISs) have provided opportunities for decision-makers in the organizations to evaluate and diagnose the dynamics of operations and financial circumstances effectively.

\section{The Study's Objectives}

The study aims to develop a conceptual framework for exploring the critical success factors that affect the quality of accounting information systems and the expected performance. The knowledge of the CSFs that affects the quality of AIS assists organizations to improve and develop their accounting information systems (AIS).

\section{Literature Review}

Accounting information system is defined that it is the information system that is used as a framework by using the physical resources to transform economic data into useful information (Willkinson \& Cerullo, 2007). Successful decisions depend on the accuracy of the financial accounting information communicated to management, on a timely basis, this known by "Information Quality". An effective financial information system needs to integrate different types of information from different sources (Romney \& Steinbart, 2012). The quality of accounting information system depends on the right combination of factors such as accuracy, reliability, security, flexibility, timeliness, audit ability, and the user's satisfaction. Quality accounting information system, from the integration perspective, is the efficiency and effectiveness of an accounting information system that is used (Syaifullah, 2014).

The critical factors are the activities required to ensure the success of a certain job or project. The critical success factors that confirm data quality in accounting information systems has been identified but the relationship between the two has not been empirically examined yet. Measurement validation of the critical success factors and data quality in accounting information systems as well as knowledge about which of the critical success factors has a relationship with data quality in accounting information systems will improve data quality. There are six critical success factors that could be considered as critical success factors for data quality in accounting information systems; "top management commitment, middle management commitment, input controls, suitability of accounting information system, teamwork and personnel competence" (Xu, 2003).

The critical success factors do not only affect the quality of accounting information system, but it also affects its expected performance. Expected performance is defined as the act of performing something successfully and using knowledge as distinguished from merely possessing it. And the performance measurement, which is generally defined as the regular measurement of outcomes and results, generates reliable data on the effectiveness and efficiency of programs (BECA, 2015). The dimension of the quality of accounting information system is efficiency, which is the size ratio of the amount produced at a cost that has been incurred. Effectiveness is the measurement of the extent to which an accounting information system has achieved its goals and it can be computed by dividing the goals actually achieved by the total of these goals (Stair \& Reynolds, 2009).

\section{Method}

The primary data needed for the study objectives were collected through a survey conducted among different Jordanian companies. A questionnaire has been designed for this purpose, and it was distributed randomly to the working employees in these companies and to different management levels in May 2015. The number of questionnaires analyzed were (104) questionnaires. Data were collected and analyzed using the statistical program Smart PLS.

Quantitative data were collected using a self-administered questionnaire, in which the employees were asked to state the likelihood (on a 5-point scale: [5] strongly agree; [4] agree; [3] neutral; [2] disagree; [1] strongly disagree), (Sekaran \& Bougie, 2015). 150 copies of the questionnaire were distributed to the respondents but only 104 were retrieved (69\%) and analyzed. Other data were collected from secondary sources as periodicals, books, and dissertations.

\subsection{Statistical Analysis}

The Statistical Package for Social Sciences (SPSS) was used to analyze the collected data. Statistical Analysis 
tools include: Descriptive Statistics, mainly frequencies and percentages, were used to analyze sample characteristics according to job title, educational level, professional certificates, and experience. Correlation, Inter-correlation, and Path Coefficient were also used to analyze statistically the study's variables. Additionally, Cronbach's Alpha was used to test the reliability of the scale.

\subsection{Research Design}

The research model identified the critical factors of accounting information systems' quality in terms of top management support, education and training, continuous improvement, user involvement, and risk management. The six dimensions of the quality of accounting information systems, which were identified in this paper, were accuracy, audit ability, reliability, security, timeliness, flexibility, and user satisfaction. In general, outcomes measurement has an important communications role making groups and organizations aware of what is to success and the areas of evaluation. Based on the literature review, the framework of research proposes the following three expected outcomes that have to be considered and monitored for the purpose of evaluating the quality of AIS and its impact on the accounting function: efficiency, effectiveness, and the integration of accounting and financial information from different sources, as illustrated in Figure (1).

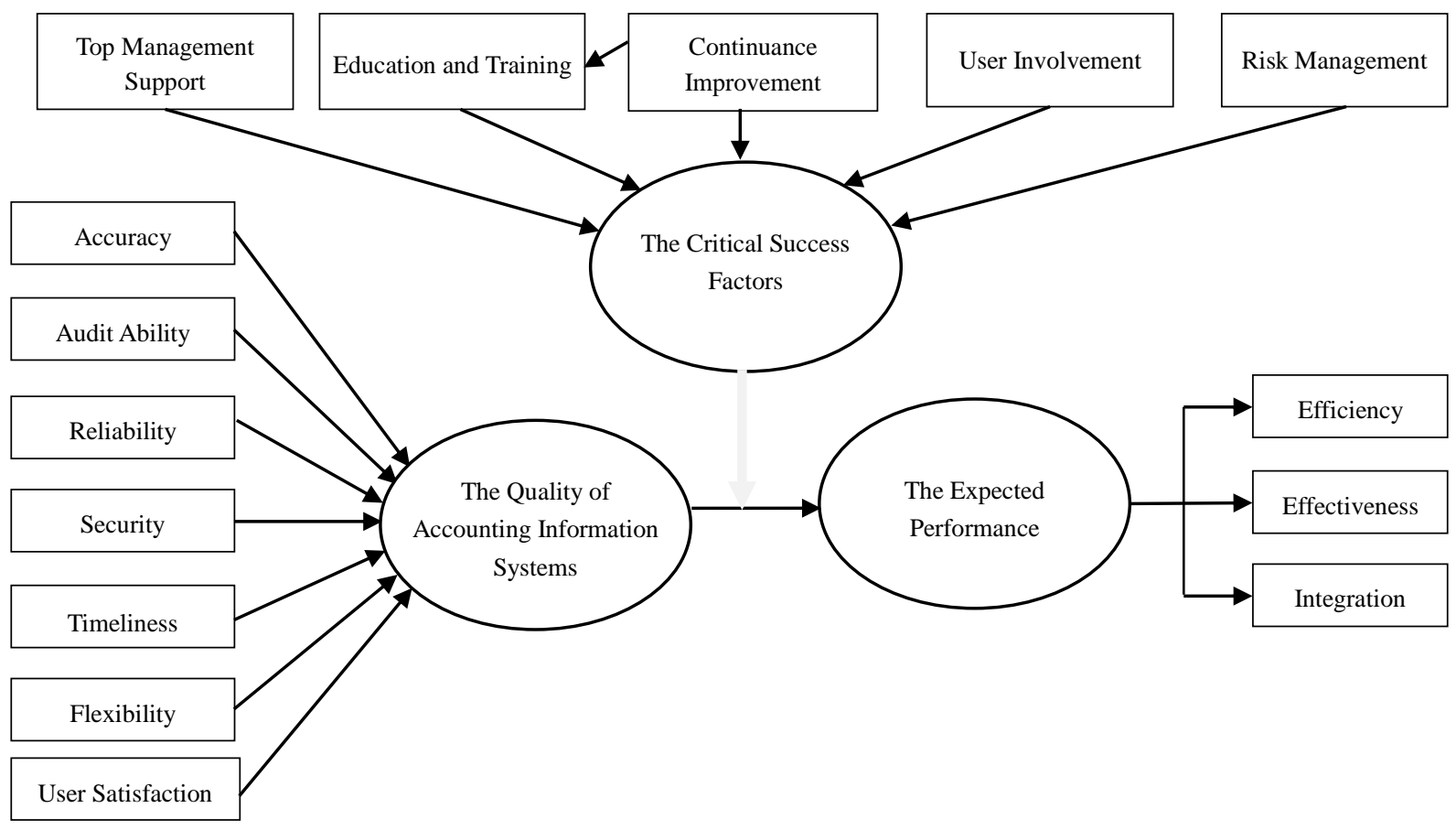

Figure 1. Research model

\subsection{Study's Hypotheses}

H1: There is an effect of the critical success factors on the quality of accounting information system.

$\mathrm{H} 2$ : There is an effect of the quality of accounting information system on the firm's expected performance.

\subsection{Data Analysis and Findings}

\subsubsection{Reliability Test}

Cronbach alpha was used to test the internal reliability of the scale instrument. In this study, 0.60 or higher is considered acceptance [28]. As shown in Table 2, the Cronbach's Alpha $(\alpha)$ ranged from 0.779 to .965. It is obvious that all values of alpha were high which indicate that the items were highly correlated and consequently highly consistent. Table 1 shows the Cronbach's alpha value for each scale:

Table 1. Cronbach alpha

\begin{tabular}{cc}
\hline & Cronbach Alpha \\
\hline Critical Success Factors & 0.977042 \\
Expected Performance & 0.842807 \\
Quality AISs & 0.926093 \\
\hline
\end{tabular}




\subsubsection{Sample Characteristics}

The respondents were $83.6 \%$ male and $16.4 \%$ female aged between 25 years and 45 years. Most respondents had average experience more than 5 years. $50 \%$ of the respondents were clerks, $29.8 \%$ officers; head of department $11.5 \%$ and $8.7 \%$ were chief financial officers (CFO). Most of respondents $(80.7 \%$ ) had a bachelor's degree, Master degree (15.4\%) and Ph.D. degree (3.8). Demographic description is shown in Table 2.

Table 2. Demographic description for the Pivot study

\begin{tabular}{llll}
\hline Variable & Group & Frequencies & $\%$ \\
\hline Sex & Male & 87 & 83.6 \\
Total & Female & 17 & 16.4 \\
Age & Less than 25 years & 104 & $100 \%$ \\
& From 26 years-35 years & 11 & 10.5 \\
& More than 36 years-45 years & 33 & 31.7 \\
Total & More than 46 years & 35 & 33.6 \\
Professional Certificate & & 25 & 24.2 \\
& Ph.D. & 104 & $100 \%$ \\
Total & Master Degree & 4 & 3.8 \\
Job Title & Bachelor's Degree & 16 & 15.4 \\
& & 84 & 80.7 \\
& Clark & 104 & $100 \%$ \\
Total & Officer & 52 & 50.0 \\
Experiences & Head of Dept. & 31 & 29.8 \\
& CFO & 12 & 11.5 \\
& & 9 & 08.7 \\
Total & Less than 5 years & 104 & $100 \%$ \\
\hline
\end{tabular}

\subsubsection{Smart PLS Results}

The structural model results are shown in Figure 2.

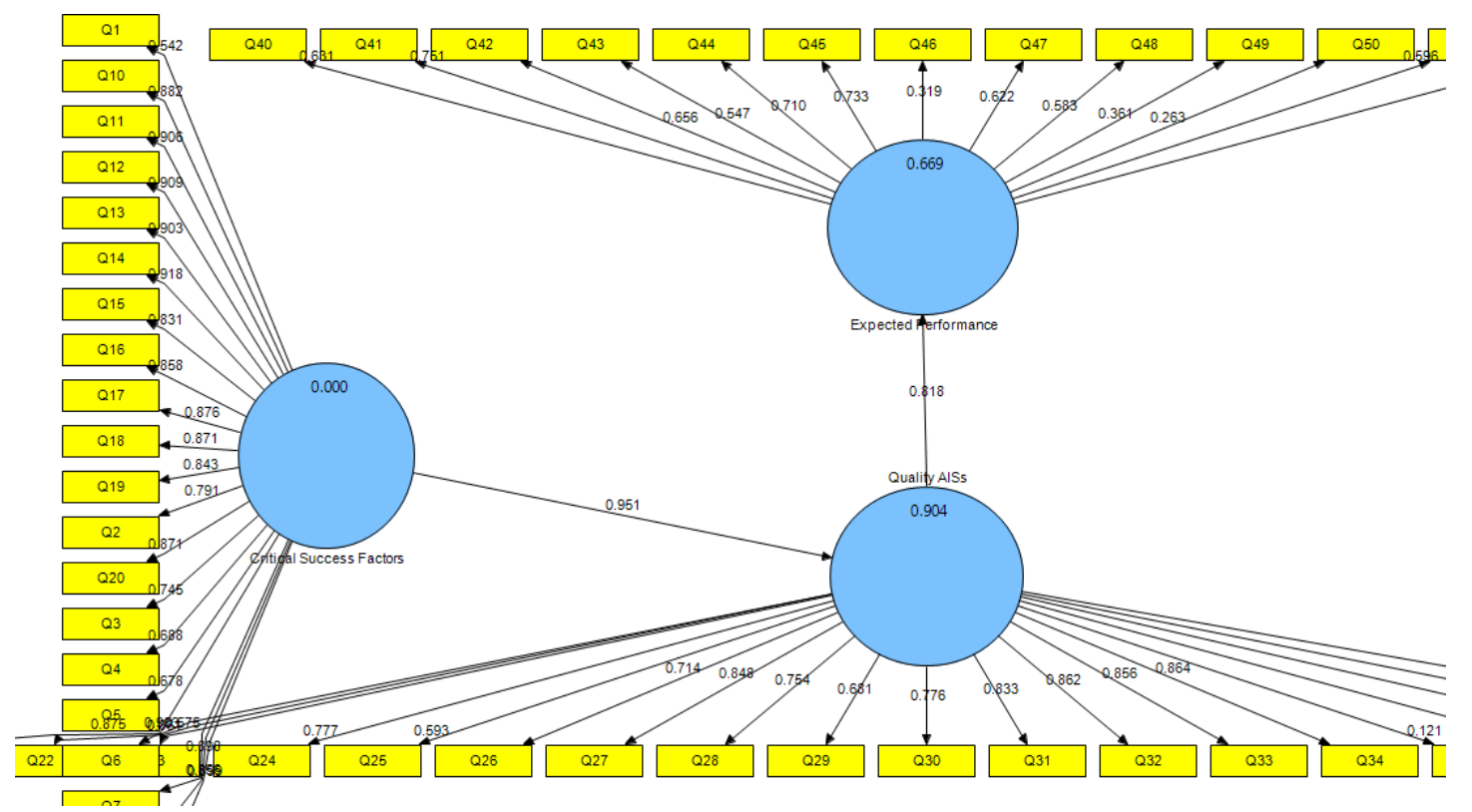

Figure 2. Model results 
Moreover, the three constructs explain 66.8 percent of the variance of the endogenous latent construct, expected performance $\left(R^{2}=0.668\right)$, and endogenous latent construct Quality of AISs $\left(R^{2}=0.903\right)$. Table 3 illustrates the $R$ square results.

Table 3. The R square of the variables

\begin{tabular}{ll}
\hline & R Square \\
\hline Critical Success Factors & \\
Expected Performance & 0.668820 \\
Quality AISs & 0.903768 \\
\hline
\end{tabular}

Examining the path coefficients, the numbers on the screen help us to determine that the critical success factors have the strongest effect on the quality of AISs with (0.950), followed by the quality of AISs effect on expected performance with (0.817). Table 4 illustrates these results.

Table 4. Path coefficients

\begin{tabular}{lll}
\hline & Expected Performance & Quality AISs \\
\hline Critical Success Factors & & 0.950667 \\
Expected Performance & & \\
Quality AISs & 0.817814 & \\
\hline
\end{tabular}

The results showed that the relationship between the three variables is statistically significant. Based on their path coefficient scores, it would appear that the effect of the Critical success factors on the Quality of AISs is significant (0.950). Moreover, the hypothesized path relationship between Quality of AISs and Expected performance is also significant (0.817), as the findings of Smart PLS rule showed that the path ccoefficient is significant if it is more than $(0.015)$.

The convergent validity assessment is associated with the Average Variance Estimated (AVE) value.The evaluation of validity criterion in table 5 illustrates that the AVE values of Critical Success Factors (0.703) and the Quality of AISs (0.542) are above the cutoff point (0.50). Therefore, these two reflective constructs demonstrate high levels of convergent validity. As for the Expected Performance construct, although its AVE values are relatively lower than the threshold (0.342), this construct has a high composite reliability score (0.86), as composite reliability scores could be used as another approach to assess a constructs' convergent validity, and thus demonstrate a valid construct (Fornell \& Larcker, 1981).

Table 5. Quality criteria

\begin{tabular}{lcccc}
\hline & AVE & Composite Reliability & R Square & Cronbach Alpha \\
\hline Critical Success Factors & 0.703781 & 0.979121 & & 0.977042 \\
Expected Performance & 0.342920 & 0.863679 & 0.668820 & 0.842807 \\
Quality AISs & 0.542399 & 0.945918 & 0.903768 & 0.926093 \\
\hline
\end{tabular}

\subsection{Conclusion}

The results showed that the relationship between the three variables is statistically significant. Based on their path coefficient scores, it would appear that the critical success factors have effect on the quality of AISs and on the expected performance, and therefore the research's hypotheses which state that the critical success factors affect the quality of AISs and the expected performance were accepted. The rapid development of IT has changed the way in which traditional accounting systems act. The increasing complexities and controversial challenges in today's accounting and financial environment require organizations to adopt and use high-quality accounting information systems. Reviewing the literature revealed that there have been very few attempts to identify the Critical Success Factors (CSFs) of the quality of AIS. Furthermore, a little attention has been paid to study the dimensions of AIS quality, CSFs, and expected outcomes in comprehensive framework. Therefore, the main objective of this research was to develop a conceptual framework for exploring the critical success factors that affect the quality of accounting information systems and the expected performance. Based on the literature review, the study's framework identified the critical factors of accounting information systems' quality in terms of top management support, education and training, continuous improvement, user involvement, and risk management. As this research results were consistent with Hamdallah et al. (2015) research which indicated that 
there was a relationship between the knowledge of using information system in industrial companies in Jordan in relation to the programs and programming, accounting and human resources.

\section{References}

Azhar, S. ( 2013). Accounting information systems: Development of risk control structure. Prime Edition. First mold. Bandung: Lingga Jaya.

Azhar, S. (2008). Sistem informasi akuntansi: struktur pengendalian risiko pengembangan. Edisi Perdana: Lingga Jaya.

BECA, (2015). Bauru of education and cultural affairs. Evaluation Division. Retrieved on July, 24. 2017 from http://www.eca.state.gov

Fornell, C., \& Larcker, D. F. (1981). Evaluating structural equation models with unobservable variables and measurement error. Journal of Marketing Research, 18(1), 39-50. https://doi.org/10.2307/3151312

Grande, E. U., Estébanez, R. P., \& Colomina, C. M. (2011). The impact of accounting information systems (AIS) on performance measures: Empirical evidence in Spanish SMEs. The International Journal of Digital Accounting Research, 11, 25-44.

Hamdallah, M. E., Yassin, M. M., \& Osman, A. (2015). Using information systems in Jordanian industrial companies and its effect on employees. International Journal of Business and Social Science, 6(6), 227-231.

Kieso, D., Weygandt, J., \& Warfield, T. (2016). Intermediate Accounting (2nd ed.). John Wiley and Sons.

Loudon, K. C., \& Laudon. J. P. (2012). Management information system: Managing the digital firm (12th ed). NJ: Prentice-Hall.

Romney, M. B., \& Steinbart, P. J. (2012). Accounting information system (12th ed.). Prentice Hall.

Sekaran, U., \& Bougie, R. (2015). Research methods for business: A skill building approaches (2nd ed.). Chichester: John Wiley \& Sons Ltd.

Stair, R. M., \& Reynolds, G. W. (2010). Principles of information systems, course technology (9th ed.). NY: Mc-Graw-Hill.

Syaifullah, M. (2014). Influence organizational commitment on the quality of accounting information system. International Journal of Scientific \& Technology Research, 3(9), 299-305.

Uma, S. (2003). Research method for business: A skill building approach (7th ed.). John Wiley and Sons, New York.

Willkinson, W. J., \& Cerullo, M. J. (2000). Accounting information system essential concept and application (4th ed.). New York, John Wiley \& Sons.

Xu, H. (2003). Critical success factors for accounting information systems data quality. Unpublished Ph.D. dissertation, University of Southern Queensland.

\section{Copyrights}

Copyright for this article is retained by the author(s), with first publication rights granted to the journal.

This is an open-access article distributed under the terms and conditions of the Creative Commons Attribution license (http://creativecommons.org/licenses/by/4.0/). 